\title{
Tracking of the broadbill swordfish, Xiphias gladius, in the central and eastern North Atlantic
}

\author{
F.J. Abascal ${ }^{\mathrm{a}, *}$, J. Mejuto $^{\mathrm{b}}$, M. Quintans ${ }^{\mathrm{b}}$, B. García-Cortés ${ }^{\mathrm{b}}$, A. Ramos-Cartelle $^{\mathrm{b}}$ \\ a Instituto Español de Oceanografía, P.O. Box 1373, 38180 Santa Cruz de Tenerife, Spain \\ ${ }^{\mathrm{b}}$ Instituto Español de Oceanografía, P.O. Box 130, 15080 A Coruña, Spain
}

\section{A R T I C L E I N F O}

\section{Article history:}

Received 23 April 2014

Received in revised form 28 August 2014

Accepted 7 September 2014

Handling Editor George A. Rose

Available online 21 October 2014

\section{Keywords:}

Swordfish

Tagging

Tracking

PSAT

\begin{abstract}
A B S T R A C T
A total of 21 swordfish, Xiphias gladius, were tagged with pop-up satellite tags in northern and southeastern areas of the North Atlantic Ocean. There were seasonal patterns in the horizontal movements, with fish tagged in the central North Atlantic moving southwards from the end of the year, generally south of $25^{\circ} \mathrm{N}$, and returning to the temperate foraging grounds, north of $40^{\circ} \mathrm{N}$, in spring. Although movements mainly took place latitudinally, fish tracks showed connectivity between the north central, north western, south eastern and north eastern North Atlantic. Average estimated daily displacements were $24.7 \pm 19.5 \mathrm{~km} \mathrm{day}^{-1}$, and could average up to $\sim 100 \mathrm{~km} \mathrm{day}^{-1}$ in some months. The longest track recorded totaled more than $10,000 \mathrm{~km}$. Swordfish showed remarkable physiological versatility, inhabiting waters with SSTs ranging from 10.1 to $28.6^{\circ} \mathrm{C}$, and subject to environmental temperatures of $c .4^{\circ} \mathrm{C}-28^{\circ} \mathrm{C}$, with daily ranges frequently over $15^{\circ} \mathrm{C}$ (mean $9.2 \pm 5.7$ ). Fish showed a clear diel pattern in vertical behavior, feeding at 300-600 m deep during daytime and staying in the mixed layer at night. There was a significant relationship between nocturnal depth and moonphase, quarter and sea surface temperature. The results of the present study are in agreement with the current separation between North Atlantic, Mediterranean and South Atlantic stocks, but suggest that the assumption of a single homogeneous stock in the North Atlantic might be overly simplistic. Further tagging studies, with special emphasis in areas and seasons not covered so far and in combination with other techniques, are still needed to elucidate the uncertainties of Atlantic swordfish stock structure.
\end{abstract}

(ㄷ) 2014 Elsevier B.V. All rights reserved.

\section{Introduction}

The broadbill swordfish, Xiphias gladius, is the most widely distributed billfish species (Palko et al., 1981). It is also the most important in terms of commercial interest, and there are fisheries targeting this species with different gears all over the world (FAO, 2012).

The status of the swordfish stocks varies depending on the ocean and population considered. Latest stock assessments indicate swordfish stocks are overexploited in the Mediterranean Sea, moderately to over-exploited in the South Pacific stock/s considered (depending on the region and model assumptions), and underexploited in the Indian Ocean in the last year of the assessment model

\footnotetext{
* Corresponding author. Present address: Secretariat of the Pacific Community. P.O. Box D5, 98848 Noumea, New Caledonia. Tel.: +34 922549400.

E-mail address: francisco.abascal@ca.ieo.es (F.J. Abascal).
}

(2009), after a reduction of the fishing effort and catches (Anon, 2012; Hinton and Maunder, 2011; Davis et al., 2013; Anon, 2011).

In the Atlantic Ocean, swordfish are managed by the International Commission for the Conservation of Atlantic Tunas (ICCAT). Past assessments (before 1999 and 2002 for the southern and northern stocks, respectively) indicated the Atlantic stocks were overfished and that overfishing was occurring. However, the most recent assessments and fishery indicators suggest a successful recovery of both stocks, attributed to catch limits and other regulations implemented at national and multilateral level (Anon, 2012; Neilson et al., 2013; Anon, 2013; Anon, in press). The management actions and other factors (mainly catches lower than total allowable catch) have resulted in a recovery of the Atlantic populations to levels that would support the maximum sustainable yield (MSY). However, the results mentioned above are subject to uncertainties related to the biology of the species (e.g., growth and maturity schedules) and other factors, like the conflicting trends among standardized catch-per-unit effort indices. One of the main limitations in current stock assessments is the lack of a 
precise knowledge on the structure of the stocks and boundaries. In the Atlantic Ocean (including the Mediterranean Sea) swordfish is managed as three different stock units, namely North Atlantic and South Atlantic, separated at $5^{\circ} \mathrm{N}$, and a Mediterranean stock. The ICCAT have defined the stock structure of the swordfish based on a pool of scientific evidence obtained over decades, such as detailed fishery data, biology parameters, tagging results, trends of abundance, size information and genetic studies (Anon, 2007). Recent genetic studies have shown a clear genetic differentiation between the Atlantic, Indian and Pacific Oceans versus the Mediterranean Sea. Little genetic differentiation within the North Atlantic was found in several studies and small but significant genetic differences were obtained between the North and South Atlantic units considered. However, the debate about the stock structure and boundaries between the Atlantic units and in other oceans remains unresolved. Moreover, recent pop-up tagging studies (Neilson et al., 2009, 2013) indicate relatively low mixing between the swordfish of the westernmost and the central-eastern areas of the North Atlantic, probably suggesting a more complex geographic stock structure than is currently assumed.

Conventional tagging is a useful and complementary tool for the definition of stock units and boundaries, and has provided information about swordfish growth (Restrepo, 1990; Kasapidis et al., 2007), and movements and mixing among Atlantic areas (for review, see Neilson et al., 2007), despite the low level of tag reporting, as compared with tunas, other billfish or large pelagic sharks (Anon, 2007). Post-release mortality, caused by the low resilience of swordfish to the fishing gears used, is a limitation for successful tagging experiments on this species (e.g., Abascal et al., 2010), in addition to the disappointing low number of conventional tags recoveries regularly reported $-3.6 \%$ on average according to the ICCAT Secretariat database current to March 2006 (Neilson et al., 2007). Information from conventional tags depends on the spatiotemporal tagging design, the fishing effort distribution of the fleets potentially recovering tagged fish, the reporting rate by fleet, as well as many other factors. Previous conventional tagging studies have indicated that conclusions about stock structure and mixing of swordfish in the North Atlantic based on conventional tagging studies are highly dependent on the spatial and temporal strata covered by the experiments (e.g., Tal Sperling et al., 2005). Wider tagging designs regularly produce a broader overview of the movements of large pelagic fish, as was the case for Atlantic swordfish when the tagging activities were geographically expanded (García-Cortés et al., 2003, Mejuto et al., 2005; Anon, 2007).

Electronic tags have proven to be a useful tool for the study of the movements and habitat preferences of large pelagic species in recent years (Nielsen et al., 2009). The main advantage of this technology is that it is, to a large extent, fishery independent, since fish can be tracked outside of the fishing grounds. However, limitations related to swordfish handling resilience have only allowed for the deployment of tags attached externally (e.g., Carey and Robinson, 1981; Sedberry and Loefer, 2001; Takahashi et al., 2003; Loefer et al., 2007; Neilson et al., 2009; Abascal et al., 2010; Sepulveda et al., 2010; Dewar et al., 2011; Hoolihan et al., 2011; Abecassis et al., 2012; Evans et al., 2014) in contrast with other methodologies (e.g., implantable archival tags) extensively used in other large pelagic species.

Investigations on large scale movements of swordfish based on electronic tagging techniques are very recent. Takahashi et al. (2003) described a cyclic migration pattern of swordfish off east Japan based on the temperature records of an externally attached archival tag. More recently, pop-up satellite tags (PSATs) have been used to describe the movement of swordfish in the south Pacific (Holdsworth et al., 2007; Abascal et al., 2010; Evans et al., 2014) and North Pacific Ocean (Dewar et al., 2011; Abecassis et al., 2012).
The only study carried out so far in the Atlantic Ocean (Neilson et al., 2009) found that fish tagged off eastern Canada carried out long distance migrations, and displayed a consistent pattern of movement, with residence in temperate waters from June to October, followed by a southwards migration to the Caribbean Sea, with fish remaining there until April and then returning to the same feeding grounds. The results of that study, with fish mainly moving latitudinally and never east of $55^{\circ} \mathrm{W}$, question the current assumption of a single stock in the North Atlantic Ocean.

The objective of this study was to contribute to the knowledge on migrations and habitat preferences of swordfish in the North Atlantic Ocean, using pop-up satellite archival tags in the central and eastern North Atlantic, areas which have not been previously covered.

\section{Materials and methods}

A total of 21 swordfish were tagged using MK10 PSATs from Wildlife Computers. Fourteen PSATs were deployed in October-November 2008 southeast of the Grand Banks, around $35^{\circ} \mathrm{N}-45^{\circ} \mathrm{N}$ and $040^{\circ} \mathrm{W}-050^{\circ} \mathrm{W}$. The remaining seven fish were tagged in December 2010 north of the Cape Verde archipelago, around $20^{\circ} \mathrm{N}-23^{\circ} \mathrm{N}$ and $020^{\circ} \mathrm{W}-025^{\circ} \mathrm{W}$ (Table 1 ).

Tagging was carried out opportunistically during the fishing activity of two commercial surface longliners targeting swordfish. Tags were attached by a monofilament leader with silicone tubing to a nylon dart. Tags were inserted into the dorsal musculature of the swordfish close to the first dorsal fin with the aid of a tagging pole once the fish was brought alongside the vessel. A conventional spaghetti tag was also placed around the monofilament for identification of the fish after the pop-up tag release in case of further recapture (Neilson et al., 2009). Only fish in seemingly prime conditions and measuring more than $135 \mathrm{~cm}$ lower jaw fork length ( $\mathrm{ca}$. $30 \mathrm{~kg}$ in round weight) were selected and tagged (mean $160 \pm 19 \mathrm{~cm}$, range $135-215 \mathrm{~cm}$ ). Both length and weight of the fish were visually estimated with the assistance of the crew.

Tags were programed to summarize data on time-attemperature and time-at-depth in predefined bins at intervals of 6,12 or $24 \mathrm{~h}$ (Table 1 ), and the deployment duration was set at 365 days. Depth bin limits were set at 0,10, 25, 50, 75, 100, 150, 200, $250,300,350,400$ and $600 \mathrm{~m}$, and temperature bin limits were 5, $10,12,14,16,17,18,19,20,22,24,26$ and $28^{\circ} \mathrm{C}$. Tag transmitted information was first processed using manufacturer software (DAP processor, Wildlife Computers). Tracks were estimated by Collecte Localisation Satellite (CLS, Ramonville Saint-Agne, France) using a Kalman filter/smoother approach constrained by light-level, sea surface temperature (daily fields obtained at a $9 \mathrm{~km}$ resolution by blending microwave and infrared SST from REMSS) and bottom topography (ETOPO2) as described in Royer and Lutcavage (2009).

Information on vertical behavior was analyzed in relation to the area and time of the day. Due to the diel pattern in vertical behavior, only those histograms that were estimated to take place completely during daytime or nighttime were selected. Sunrise and sunset times were calculated using the Matlab script "sunrise", from the Woods Hole Coastal and Marine Science Center. A generalized linear model, followed by ANOVA, was used to analyze the relationship between nighttime median depth (calculated using the center of the depth bins) and sea surface temperature (as measured by the tag), quarter of the year and moon visible fraction (from the United States Naval Observatory, available at http://aa.usno.navy.mil/data/docs/MoonFraction.php).

Maps were constructed using Matlab R2011b m_map package (Pawlowicz, 2011), and plots were performed in R (R Core Team, 2013), using packages ggplot and plotrix. Data analysis was 
Table 1

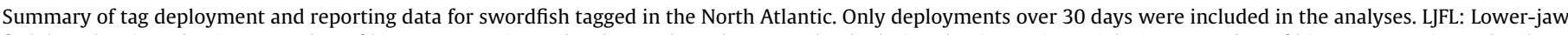

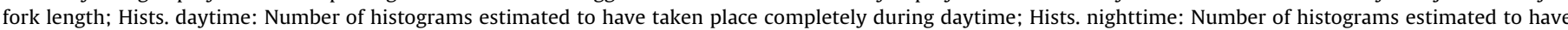
taken place completely during nighttime; Hist-hr: Number of hours summarized in each histogram; TAL: Time at liberty.

\begin{tabular}{|c|c|c|c|c|c|c|c|c|c|c|c|}
\hline \multirow[t]{2}{*}{ Tag \# } & \multirow[t]{2}{*}{ LJFL $(\mathrm{cm})$} & \multirow[t]{2}{*}{ Hists. day } & \multirow[t]{2}{*}{ Hists. night } & \multirow[t]{2}{*}{ Hist-h } & \multicolumn{3}{|l|}{ Deployment } & \multicolumn{3}{|l|}{ Reporting } & \multirow[t]{2}{*}{ TAL (days) } \\
\hline & & & & & Date & Lat. & Long. & Date & Lat. & Lon. & \\
\hline 73570 & 140 & - & - & 6 & $30 / 10 / 2008$ & $38^{\circ} 46^{\prime} \mathrm{N}$ & $042^{\circ} 42^{\prime} \mathrm{W}$ & - & - & - & - \\
\hline 79811 & 170 & 82 & 80 & 6 & $31 / 10 / 2008$ & $38^{\circ} 51^{\prime} \mathrm{N}$ & $043^{\circ} 07^{\prime} \mathrm{W}$ & $31 / 10 / 2009$ & $34^{\circ} 52^{\prime} \mathrm{N}$ & $045^{\circ} 51^{\prime} \mathrm{W}$ & 365 \\
\hline 79810 & 165 & 46 & 22 & 6 & $31 / 10 / 2008$ & $38^{\circ} 51^{\prime} \mathrm{N}$ & $043^{\circ} 07^{\prime} \mathrm{W}$ & $31 / 10 / 2009$ & $10^{\circ} 59^{\prime} \mathrm{N}$ & $025^{\circ} 38^{\prime} \mathrm{W}$ & 365 \\
\hline 79806 & 147 & - & - & 6 & $31 / 10 / 2008$ & $38^{\circ} 46^{\prime} \mathrm{N}$ & $043^{\circ} 06^{\prime} \mathrm{W}$ & - & & & - \\
\hline 79803 & 140 & - & - & 6 & $01 / 11 / 2008$ & $38^{\circ} 30^{\prime} \mathrm{N}$ & $043^{\circ} 05^{\prime} \mathrm{W}$ & - & & & - \\
\hline 79800 & 160 & 90 & 47 & 6 & $04 / 11 / 2008$ & $37^{\circ} 58^{\prime} \mathrm{N}$ & $042^{\circ} 52^{\prime} \mathrm{W}$ & $30 / 09 / 2009$ & $45^{\circ} 02^{\prime} \mathrm{N}$ & $025^{\circ} 53^{\prime} \mathrm{W}$ & 330 \\
\hline 79799 & 140 & - & - & 6 & $05 / 11 / 2008$ & $38^{\circ} 08^{\prime} \mathrm{N}$ & $042^{\circ} 54^{\prime} \mathrm{W}$ & - & & & - \\
\hline 54576 & 215 & - & - & 6 & $09 / 11 / 2008$ & $42^{\circ} 07^{\prime} \mathrm{N}$ & $047^{\circ} 26^{\prime} \mathrm{W}$ & - & & & - \\
\hline 54572 & 185 & - & - & 6 & $10 / 11 / 2008$ & $42^{\circ} 20^{\prime} \mathrm{N}$ & $047^{\circ} 20^{\prime} \mathrm{W}$ & - & & & - \\
\hline 54562 & 145 & 36 & 35 & 6 & $10 / 11 / 2008$ & $42^{\circ} 23^{\prime} \mathrm{N}$ & $047^{\circ} 29^{\prime} \mathrm{W}$ & $12 / 08 / 2009$ & $42^{\circ} 23^{\prime} \mathrm{N}$ & $041^{\circ} 50^{\prime} \mathrm{W}$ & 275 \\
\hline 54567 & 135 & 8 & 88 & 6 & $12 / 11 / 2008$ & $42^{\circ} 00^{\prime} \mathrm{N}$ & $047^{\circ} 30^{\prime} \mathrm{W}$ & 09/02/2009 & $37^{\circ} 37^{\prime} \mathrm{N}$ & $039^{\circ} 55^{\prime} \mathrm{W}$ & 89 \\
\hline 54560 & 145 & - & - & 6 & $12 / 11 / 2008$ & $42^{\circ} 01 \mathrm{~N}$ & $047^{\circ} 24^{\prime} \mathrm{W}$ & - & & & - \\
\hline 54505 & 180 & 53 & 90 & 6 & $13 / 11 / 2008$ & $42^{\circ} 00^{\prime} \mathrm{N}$ & $047^{\circ} 08^{\prime} \mathrm{W}$ & 02/06/2009 & $40^{\circ} 23^{\prime} \mathrm{N}$ & $066^{\circ} 03^{\prime} \mathrm{W}$ & 201 \\
\hline 54504 & 180 & 47 & 65 & 6 & $14 / 11 / 2008$ & $40^{\circ} 05^{\prime} \mathrm{N}$ & $047^{\circ} 22^{\prime} \mathrm{W}$ & 09/09/2009 & $43^{\circ} 20^{\prime} \mathrm{N}$ & $046^{\circ} 23^{\prime} \mathrm{W}$ & 299 \\
\hline 54569 & 160 & - & - & 12 & $08 / 12 / 2010$ & $22^{\circ} 47^{\prime} \mathrm{N}$ & $024^{\circ} 20^{\prime} \mathrm{W}$ & $11 / 12 / 2010$ & $23^{\circ} 14^{\prime} \mathrm{N}$ & $024^{\circ} 51^{\prime} \mathrm{W}$ & 3 \\
\hline 54503 & 160 & - & - & 12 & $08 / 12 / 2010$ & $22^{\circ} 51^{\prime} \mathrm{N}$ & $023^{\circ} 57^{\prime} \mathrm{W}$ & - & & & - \\
\hline 54500 & 160 & 0 & 9 & 12 & $23 / 11 / 2010$ & $20^{\circ} 43^{\prime} \mathrm{N}$ & $024^{\circ} 40^{\prime} \mathrm{W}$ & $10 / 06 / 2011$ & $9^{\circ} 00^{\prime} \mathrm{N}$ & $020^{\circ} 40^{\prime} \mathrm{W}$ & 199 \\
\hline 79797 & 160 & - & - & 24 & $11 / 12 / 2010$ & $23^{\circ} 05^{\prime} \mathrm{N}$ & $020^{\circ} 58^{\prime} \mathrm{W}$ & $24 / 12 / 2010$ & $21^{\circ} 28^{\prime} \mathrm{N}$ & $023^{\circ} 30^{\prime} \mathrm{W}$ & 13 \\
\hline 79798 & 170 & - & - & 24 & $20 / 12 / 2010$ & $20^{\circ} 36^{\prime} \mathrm{N}$ & $021^{\circ} 56^{\prime} \mathrm{W}$ & $22 / 12 / 2010$ & $20^{\circ} 31^{\prime} \mathrm{N}$ & $022^{\circ} 00^{\prime} \mathrm{W}$ & 2 \\
\hline 79801 & 145 & - & - & 24 & $28 / 12 / 2010$ & $20^{\circ} 23^{\prime} \mathrm{N}$ & $022^{\circ} 58^{\prime} \mathrm{W}$ & $13 / 02 / 2011$ & $19^{\circ} 30^{\prime} \mathrm{N}$ & $030^{\circ} 03^{\prime} \mathrm{W}$ & 47 \\
\hline 79804 & 170 & 12 & 6 & 12 & $29 / 12 / 2010$ & $20^{\circ} 47^{\prime} \mathrm{N}$ & $022^{\circ} 30^{\prime} \mathrm{W}$ & $21 / 11 / 2011$ & $43^{\circ} 24^{\prime} \mathrm{N}$ & $009^{\circ} 47^{\prime} \mathrm{W}$ & 327 \\
\hline
\end{tabular}

restricted to those tags that reported and with deployment durations over 30 days.

\section{Results}

\subsection{Deployment duration and data retrieval}

Reporting rate varied among tagging surveys. In 2008, seven of the tags (50\%) did not report, two detached at the preset date and the remaining five tags detached after $239 \pm 96$ days on average. In 2010, in the survey north of Cape Verde Islands, one out of the seven tags (14\%) did not report, and the remaining six tags detached prematurely after $98 \pm 135$ days (Table 1 ). Mean lower jaw fork length (LJFL) was not significantly different between reporting and non-reporting tags ( $t$-test; $p>0.05$ ).

\subsection{Horizontal movements}

The analysis of the horizontal movements revealed seasonal patterns, with fish generally moving south by the end of the year and returning to the temperate foraging grounds in spring (Figs. 1A and 2). Although movements mainly took place latitudinally, and most of the tags popped-off near the deployment location, fish tracks showed some connectivity across the north Atlantic. One of the seven fish tagged in the central North Atlantic, around $40^{\circ} \mathrm{N}$ and $045^{\circ} \mathrm{W}$, moved to the western North Atlantic (west of $065^{\circ} \mathrm{W}$ ), five moved south of $25^{\circ} \mathrm{N}$, one of them reaching latitudes close to the equator and then moving to the area of the Cape Verde Islands, and another one moving east of $030^{\circ} \mathrm{W}$. Of the three tags deployed north of Cape Verde archipelago, one remained in the region, another traveled south, down to $c .10^{\circ} \mathrm{N}$, and the third one reached the northeastern coast of the Iberian Peninsula, at $c$. $43^{\circ} \mathrm{N}$ and $010^{\circ} \mathrm{W}$ (Figs. $1 \mathrm{~B}$ and 2 ).

With the exception of fish \#54567, which had the shortest track (89 days) and did not show a significant displacement during that period (Fig. 3G), fish tagged south of the Grand Banks initiated a southward migration soon after tagging in late October to early November (Fig. 1A). Fish \#54562 and \#79811 were south of $25^{\circ} \mathrm{N}$ before traveling back north in March and February, respectively (Fig. 3D and F). Fish \#79800 showed a similar pattern, although it started its northward migration by the beginning of January, but showed a southward trend from mid-March to mid-April (Fig. 3E). Tags \#54504 and \#79810 reached their southernmost positions in early May and late March, respectively. Fish \#54504 returned to the area of tagging, while fish \#79810 was near the Cape Verde Islands in late July and remained there until its tag popped-off on its due date in late October (Fig. $3 \mathrm{~A}$ and $\mathrm{C}$ ). The last fish tagged in the northern region, \#54505, initially moved south, but started traveling to the west around mid-January and reached the area off Georges Banks in early June, before the tag detached.

Regarding the swordfish tagged North of Cape Verde in 2010, fish \#54500 also moved south after tagging in early December. However, once it reached an area centered near $10^{\circ} \mathrm{N}-020^{\circ} \mathrm{W}$ it remained in the region for more than four months (Fig. $3 \mathrm{H}$ ). Fish \#79804 mainly moved west after tagging, but from early May it moved in a northward direction, eventually heading west and was off the northwest coast of the Iberian Peninsula when the tag transmitted in November (Fig. 3J). Finally, fish \#79801 remained close to the area of tagging during January and moved westwards until midFebruary, when the tag detached (Fig. 3I). The estimated average daily displacement was $24.7 \pm 19.5 \mathrm{~km} \mathrm{day}^{-1}$ and reached a maximum monthly average of $\sim 100 \mathrm{~km} \mathrm{day}^{-1}$ (fish \#54504 in July). The longest track recorded totaled $10,582 \mathrm{~km}$.

\subsection{Vertical behavior and habitat preferences}

There is a clear diel pattern in swordfish vertical behavior (Fig. 4), with fish mainly staying in the mixed layer at night and descending to high depths during daytime. The daytime vertical behavior of fish in the areas southeast of the Grand Banks and around the Cape Verde archipelago was similar, with fish remaining at 400-600 m most of the time. Nighttime behavior was slightly different between both areas: while fish showed a mode around $25 \mathrm{~m}$ and a low percentage of time below $150 \mathrm{~m}$ (c. 3\%) in the northern area, in the area around Cape Verde Islands there was a shallower mode, above $10 \mathrm{~m}$ deep. At the same time, fish in this latter region spent a significant amount of time at greater depths $(17.8 \%$ of the time below $150 \mathrm{~m}$ ). However, it must be noted that all the daytime histograms in the southern region are from fish \#79810, from 

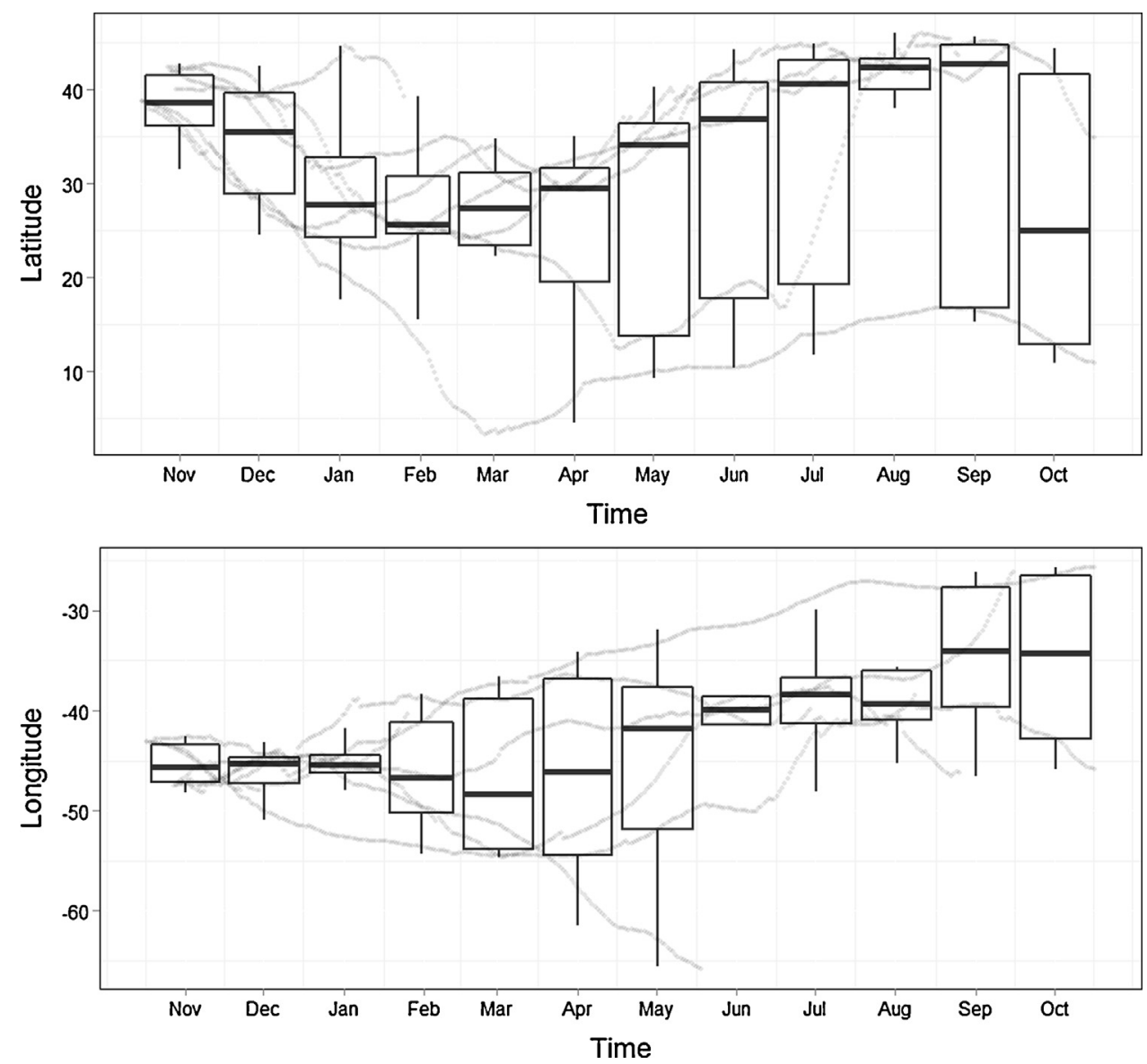

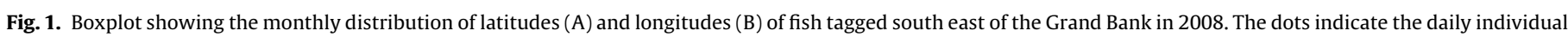
estimated positions.

the end of April to the end of October, and that there are only 16 nighttime histograms, from three fish, in the area.

The GLM reflected a significant effect of moonphase $\left(p=5.3 \times 10^{-7}\right)$, quarter $\left(p=4.7 \times 10^{-4}\right)$ and sea surface temperature $\left(p=9.9 \times 10^{-3}\right)$ over the nocturnal median depth. Fish showed a deeper night distribution close to full moon and during the last quarter of the year, as well as a shallower distribution with low sea surface temperatures (Fig. 5).

Environmental temperatures ranged between $4.0^{\circ} \mathrm{C}$ and $28.3^{\circ} \mathrm{C}$, with daily shifts frequently over $15^{\circ} \mathrm{C}$ (mean $9.2 \pm 5.7$ ), and fish

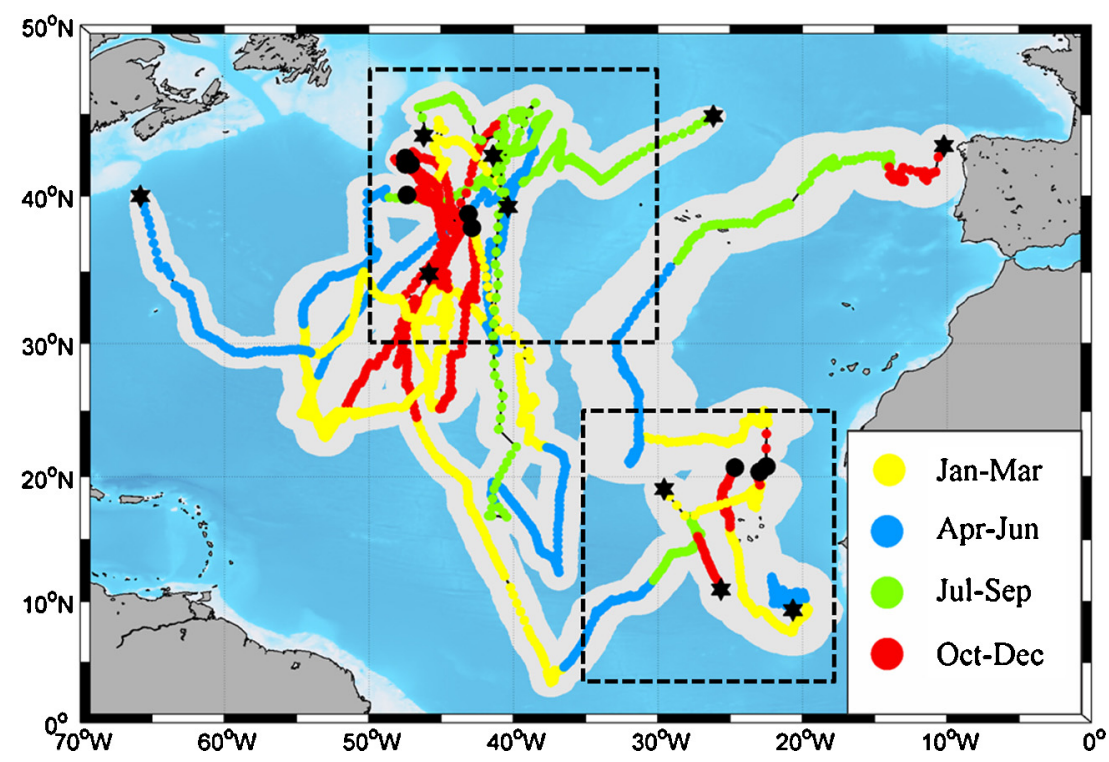

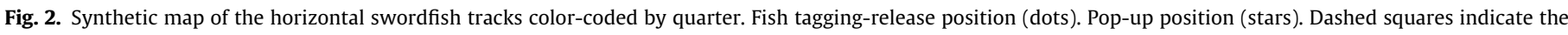
two areas used for the description of vertical distribution. 

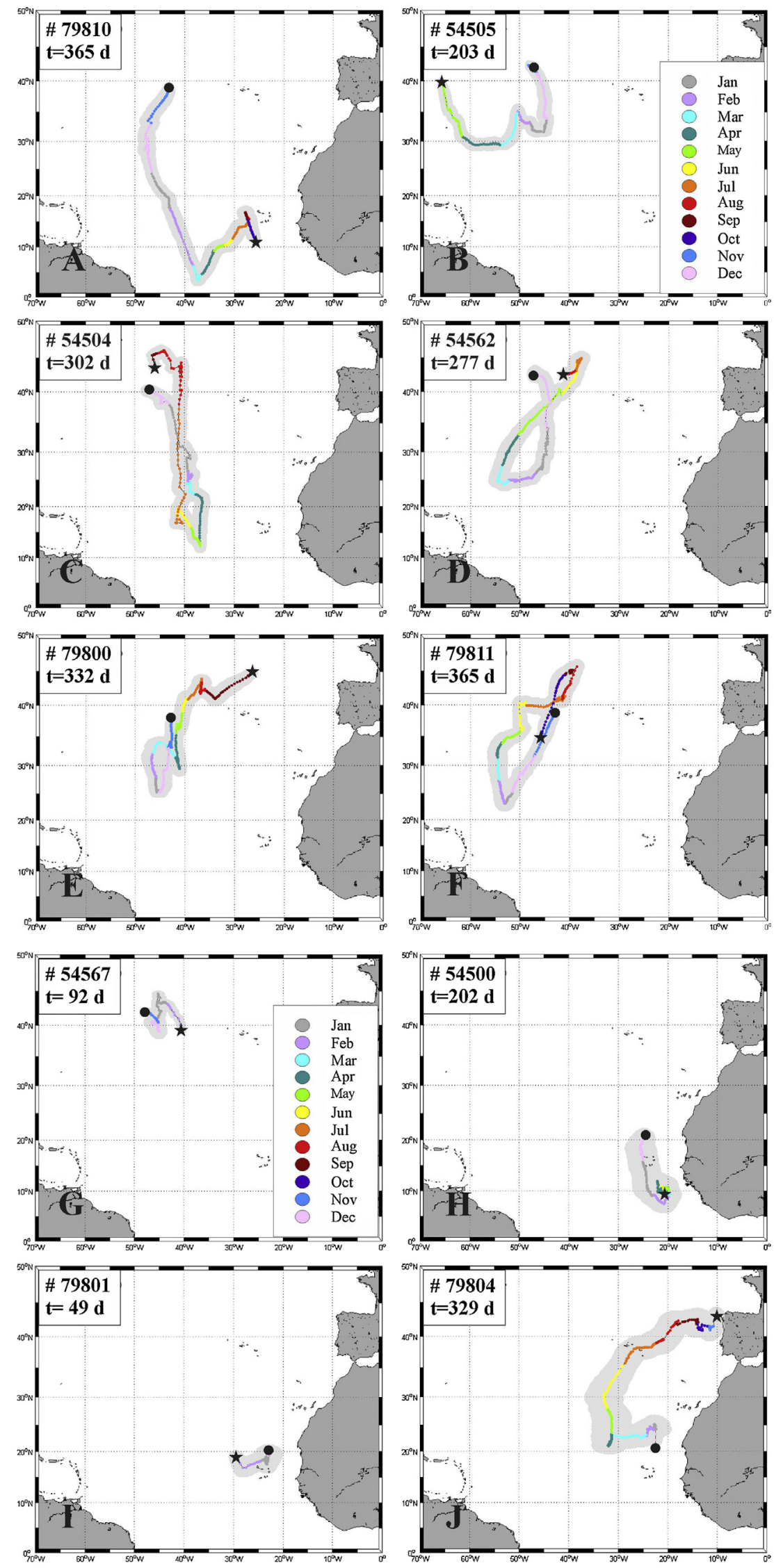

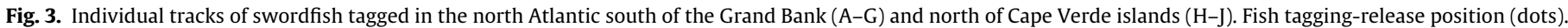
Pop-up position (stars). Number of tag (\#). Days attached $(t)$. 

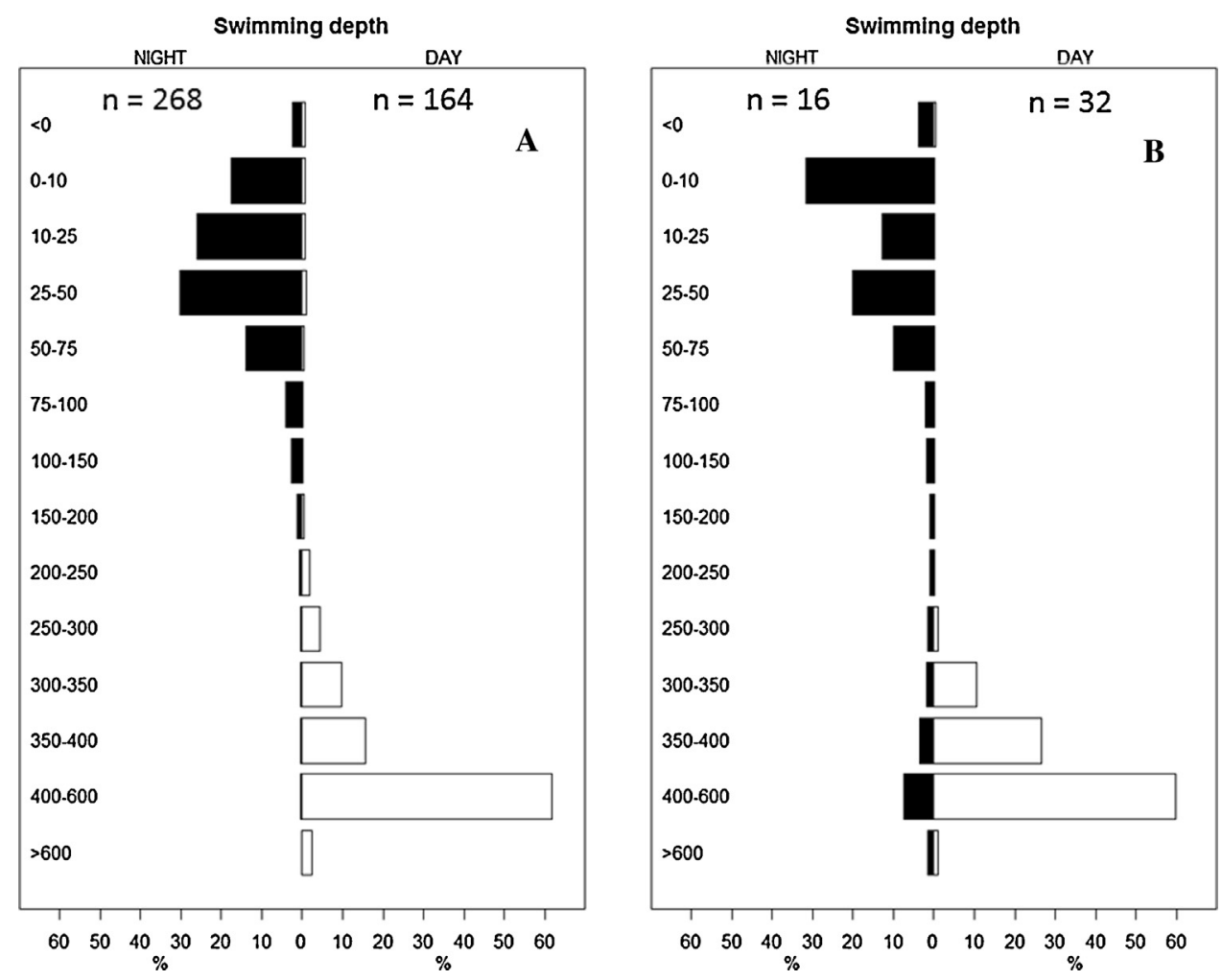

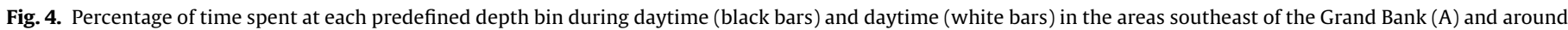
Cape Verde islands (B).
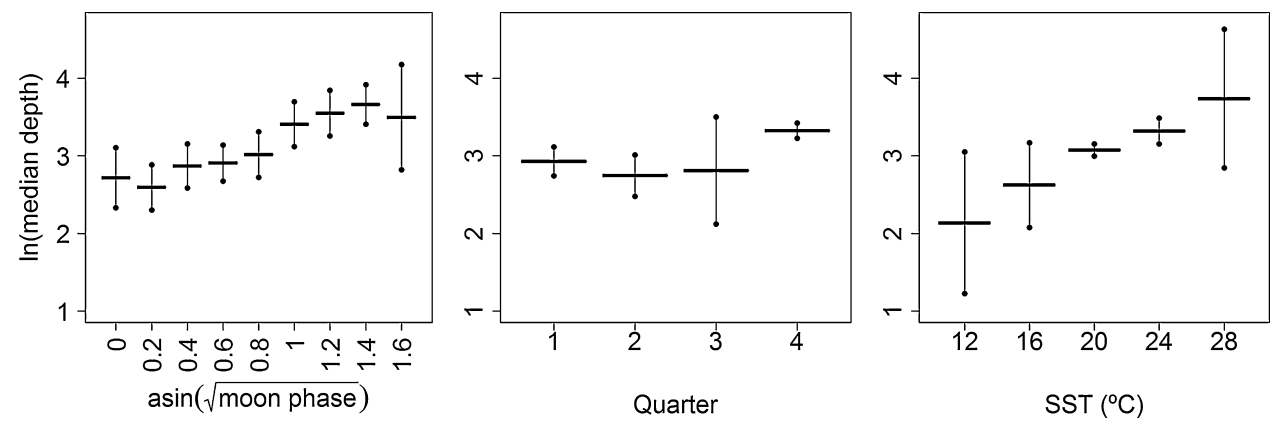

Fig. 5. Effect of quarter, moonphase and SST over median nocturnal depth (natural logarithm transformed).

inhabited sea surface temperatures from $10.0^{\circ} \mathrm{C}$ to $28.5^{\circ} \mathrm{C}$ (mean $21.9 \pm 3.2$ ) (Fig. 6). The sea surface temperature distribution shows three modes, one around $20^{\circ} \mathrm{C}$, mainly found north of $30^{\circ} \mathrm{N}$, another mode around $24.5^{\circ} \mathrm{C}$, mainly found south of $30^{\circ} \mathrm{N}$, and a third mode around $27^{\circ} \mathrm{C}$, only around Cape Verde Islands.

\section{Discussion}

The current PSAT reporting rate, of $61 \%$, was found to be low in comparison with previous studies on the same species using similar tags (e.g., 92\% from Neilson et al., 2009; 90\% from Abascal et al., 2010; 79\% from Abecassis et al., 2012). A recent review by Musyl et al. (2011) on PSAT performance estimated an overall reporting rate of $86 \%$ for Wildlife Computer tags. For most of the tags used in the current study, we did not utilize the failsafe mechanism (RD1800, Wildlife Computers ${ }^{\circledR}$ ) that cut the tether when a given depth was exceeded. Although such a device is available from the manufacturer and would prevent tags from imploding, allowing for more accurate information on the fate of the fish, it could result in a potential weakening of the tether. In our previous study in the same

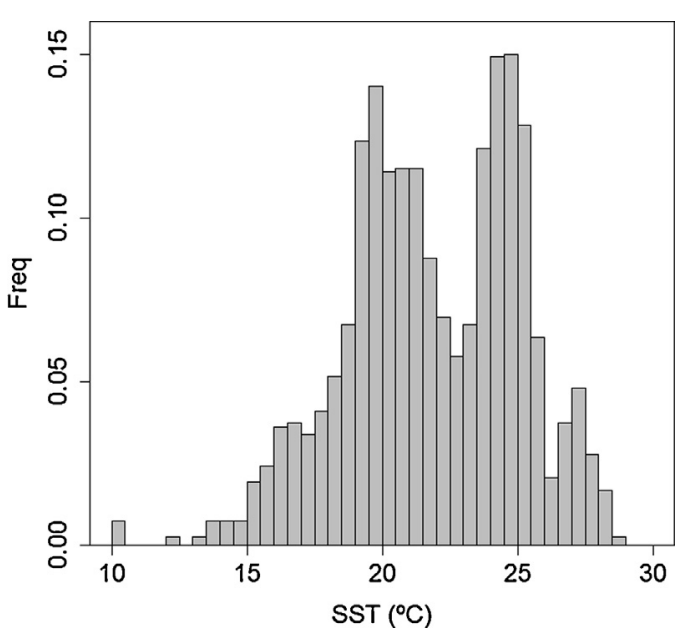

Fig. 6. Frequency histogram of the sea surface temperatures recorded by the PSATs. 
species (Abascal et al., 2010), we found that fish death generally occurs within the first few days after tagging. Therefore, the amount of information that could be obtained in the event of fish postrelease mortality would be minimal and it was decided not to use the RD1800 device. The non-reporting rate obtained in the present work is consistent with mortality estimates of previous studies. Abascal et al. (2010) estimated a post-release mortality of $40 \%$ in swordfish tagged opportunistically aboard commercial longline vessels. Values estimated from Dewar et al. (2011) indicate tagging mortalities of $22 \%$ and $38 \%$ in the western North Atlantic and in the eastern Pacific, respectively, but these estimates include fish tagged aboard recreational and harpoon vessels. Therefore, the main cause for the tags not reporting seems to be fish mortality, with the fish sinking below the rated depth for tag performance. In this regard, the development of scientific tagging survey designs seems to be more convenient than taking advantage of opportunistic tagging activities during commercial trips in the case of swordfish, considering the low resilience of this species. As an example, García-Cortés et al. (2003) found that swordfish reporting rates of conventional tags increased from $0.33 \%$ to $6.11 \%$ between opportunistic tagging activities aboard commercial vessels and scientific tagging surveys. There are several factors affecting the post-release mortality in tagging studies (Musyl et al., 2009), although it seems soaking time in longline commercial sets (frequently over $8 \mathrm{~h}$ ) might be the main source of swordfish tagging failure, when comparted with scientific surveys. In certain regions, other gears like the harpoon fishery have proven a very efficient way of tagging basking swordfish (Dewar and Polovina, 2005; Neilson et al., 2009; Sepulveda et al., 2010).

Most of the fish tagged in the current study in the central North Atlantic showed a consistent movement pattern, traveling south in late fall (Figs. $1 \mathrm{~A}$ and 2), reaching latitudes around $20-30^{\circ} \mathrm{N}$, and moving back to the feeding grounds in the central North Atlantic in early spring. However, two out of the seven fish moved further south (Fig. $3 \mathrm{~A}$ and $\mathrm{C}$ ), one of them moving south of $5^{\circ} \mathrm{N}$ (Fig. 3A). In the case of the fish tagged in the southeastern North Atlantic, the sample size was too low to infer any pattern in movement, although tracks showed large scale displacements to the northeastern Atlantic, when one of the tags detached off the northwestern coast of Spain. Results are consistent with the currently assumed stock structure, with no trans-equatorial movement or to the Mediterranean Sea observed, although the sample size and the areas/seasons covered are very limited. The only fish that seemed to visit any of the currently described spawning locations (for review, see Neilson et al., 2013) was fish \#79810 during March-April. Unfortunately, due to the size distribution of the fish tagged and the difference in size at first maturity between males and females (Neilson et al., 2013), it is not possible to infer whether the fish tagged in the current study were sexually mature or not.

Although some of the fish were tagged in areas of the central North Atlantic relatively close to those areas selected in a previous study (Neilson et al., 2009), in comparison, the migratory behavior observed in the current study was more diverse. While fish tagged in Canadian waters by Neilson et al. (2009) moved across a relatively narrow longitudinal corridor, and showed no movement to areas east of $50^{\circ} \mathrm{W}$, the tracks exhibited by the fish tagged in the north central and southeastern North Atlantic shows some degree of connectivity across the North Atlantic ocean, in spite of the relatively short deployment durations (Figs. 2 and 3). It is possible that the Gulf Stream and the convergence with colder-feeding waters of the northwestern Atlantic play an important role for more restrictive migration patterns of the swordfish within the westernmost North Atlantic regions for feeding and reproduction. The association of other large pelagic species, such as the bluefin tuna (Thunnus thynnus), with the Gulf Stream has been well documented in electronic tagging studies (e.g., Block et al., 2005; Galuardi et al., 2010). As has been the case in past conventional tagging studies
(García-Cortés et al., 2003; Mejuto et al., 2005; Anon, 2007), expanding the season, areas and sample size of pop-up tagging seems to provide information on a broader diversity of the migratory patterns of swordfish, and gives a better idea of the potential areas of mixture within the Atlantic. Another potential reason for the difference between the results of Neilson et al. (2009) and the current study is the size and sex of the fish. Large females are typically found in colder (below $18^{\circ} \mathrm{C}$ ) waters, while smaller fish and a higher proportion of males is found in warmer waters (Palko et al., 1981). The fish tagged by Neilson et al. (2009) in the feeding area were large adults (see ICCAT, 2006-2014) over $100 \mathrm{~kg}$, probably with a significant proportion of females and likely to display a reproductive migration to the southern spawning grounds. On the contrary, fish in the current study were estimated to weigh between 22 and $77 \mathrm{~kg}$, many of them having not reached the size of sexual maturity and with a higher proportion likely to be males.

In any case, and in spite of the low sample sizes, the results of the electronic tagging study by Neilson et al. (2009) and the present work should be considered as complementary, and support the currently assumed separation between the North Atlantic, the Mediterranean Sea and the South Atlantic Ocean. Nevertheless, these results also suggest that the concept of a homogeneous single stock in the North Atlantic might be overly simplistic. On the other hand, the large scale movements between regions observed in the current study and in past conventional tagging surveys, as well as other available information previously analyzed by ICCAT (Anon, 2007), like the lack of spawning grounds described so far in the eastern North Atlantic basin, do not support the existence of two separate isolated stocks either. In the case of Atlantic bluefin tuna, currently managed as two stocks separated by the $45^{\circ} \mathrm{W}$ meridian, Fromentin and Powers (2005) suggested alternative models, such as Clark's contingent and metapopulation theories. Similarly, other approaches might better describe the stock structure in the case of the Atlantic swordfish. Further tagging experiments combined with broad genetic studies and other techniques could help to elucidate the uncertainties still remaining.

Trends in latitudinal movement are comparable with the findings of Neilson et al. (2009), with fish moving south in winter and beginning the northwards migration in April-May. Similarly, Abascal et al. (2010) described a migration to subtropical waters in late fall and probably back to temperate regions in early spring in the southeastern Pacific Ocean, based on six swordfish tracked for 49-166 days. On the contrary, Abecassis et al. (2012) found no pattern in the horizontal movement of 23 fish tracked in the north Pacific, and seasonal movements in 43 swordfish tracked in the western and central South Pacific were only evident east of $165^{\circ} \mathrm{E}$ (Evans et al., 2014). Regarding other large pelagic species, Block et al. (2011) analyzed the distribution of various congener guilds in the Pacific Ocean, and also described a general pattern in latitudinal movements of large marine predators. The authors of this study found that the species tracked (bluefin and yellowfin tunas; shortfin mako, salmon and white sharks; and blue whales) generally moved south by the end of the year and moved back north around spring. They suggested this behavior might be indicative of tradeoffs between access to areas of high productivity and physiological constraints, either by the predator or their prey.

The analysis of vertical behavior presented here is limited, because of the PSAT tag model used. The diel pattern in the behavior of swordfish, and the fact that most of the histograms transmitted span both day and nighttime intervals, make it difficult to make comparisons between different datasets, since most of the differences are due to the percentage of daytime comprised in each histogram. Nevertheless, we attempted to describe the behavior of fish based on those histograms estimated to have taken place completely during day and nighttime. The number of histograms estimated to have taken place completely during day or nighttime 
was significantly higher for the fish tagged southeast of the Grand Banks in comparison with those tagged around the Cape Verde Islands (Table 1, Fig. 4), mainly due to the different binning duration. The sample size in the Cape Verde region was very limited and, in addition, most of the data came from just one fish.

As previously described (e.g., Carey and Robinson, 1981), swordfish show a clear diel vertical behavior (Fig. 4), feeding at depth on organisms in the deep scattering layer (Carey, 1990) and remaining in the mixed layer at night, where they can recover from thermal and, especially in some areas like the Cape Verde archipelago, oxygen debts acquired during the day. The association of other pelagic species, like the bigeye (Thunnus obesus) and yellowfin tuna (Thunnus albacares), with the deep scattering layer has been well described in field experiments combining sonic tracking and acoustic surveys (Josse et al., 1998). The pattern in vertical distribution was similar between both areas analyzed, with the exception of the shallower mode in nighttime depth in the area around Cape Verde Islands, compared to that in the area south east of the Grand Banks, where fish seemed to spend some time at depths over $400 \mathrm{~m}$. Interestingly, Dewar et al. (2011) also found a shallow mode and a wider range in depth during the night in fish tracked in the southwestern North Atlantic, in contrast with the values observed in the northeastern and north-central Pacific Ocean.

The differences in vertical behavior can be accounted for by several factors, like differences in the thermal structures of the water column between both areas, or variations in the nocturnal distribution of prey. There is also the possibility that the deep values could correspond to histograms that partially took place close to sunrise/sunset times, or even caused by geolocation errors and the subsequent error in the estimate of sunrise and sunset times. In addition, it must be noted that the observations in the Cape Verde area were very limited, with only 16 histograms from three different fish.

Several studies have described the relationship between swordfish nighttime depth and lunar phase (e.g., Loefer et al., 2007; Abascal et al., 2010; Dewar et al., 2011). In addition, our observations suggest that swordfish nighttime distribution might be related to other factors, like sea surface temperature or quarter of the year (Fig. 5). Although this relationship was found to be significant and could be explained by physiological reasons, especially the relationship with sea surface temperature, it must be taken with caution, due to the low sample size and the fact that it may be confounded with other factors not included in the model due to the lack of contrasts, like the area (most of the fish were concentrated in the northern area in the last quarter of the year).

Despite the limitations and problems faced when tagging billfish, the results obtained provide useful information on the stock structure of the species, which is in turn essential for the management of the population. Pop-up tagging, in combination with other techniques, provides valuable and complementary information about the complex behavior of swordfish, and allows for more biologically realistic approaches to reduce the uncertainty of assessments and promote better management of the Atlantic swordfish stocks. Taking into account the gaps in knowledge noted during the 2006 ICCAT Workshop on Swordfish Structure (Anon, 2007), it is highly recommended to continue the electronic tagging activities, with special emphasis in areas and seasons not covered so far, if possible in combination with other techniques (genetic, microchemistry, ageing, gonad histology, etc.) that help explain the variability in the dynamics of the species.

\section{Acknowledgments}

The authors would like to give their deepest thanks to all the members of the team who were involved in the surveys.
Without the help of qualified and dedicated people, such as the crew members of the longliners F/V AMEL, RIAS BAIXAN UN and the scientific observer Guzmán Ferreiros, this paper would not have been possible. This study has been developed within the framework of the project SWOATL1215 of the Instituto Español de Oceanografía. F.A. was funded by the People Programme (Marie Curie Actions) of the European Union's Seventh Framework Programme FP7/2007-2013/under REA grant agreement n 326455 during the final phase of the current study. The comments of Dr. John Neilson and an anonymous reviewer greatly improved the manuscript.

\section{Appendix A. Supplementary data}

Supplementary data associated with this article can be found, in the online version, at http://dx.doi.org/10.1016/j.fishres. 2014.09.011.

\section{References}

Abascal, F.J., Mejuto, J., Quintans, M., Ramos-Cartelle, A., 2010. Horizontal and vertical movements of swordfish in the Southeast Pacific. ICES J. Mar. Sci. 67, 466-474.

Abecassis, M., Dewar, H., Hawn, D., Polovina, J., 2012. Modeling swordfish daytime vertical habitat in the North Pacific Ocean from pop-up archival tags. Mar. Ecol. Prog. Ser. 452, 219-236.

Anon, 2007. Report of the 2006 ICCAT workshop on swordfish stock structure. Heraklion, Crete, Greece, (March 13-15, 2006). Collect. Vol. Sci. Pap. ICCAT 61, 1-23.

Anon., 2011. Report of the Ninth Session of IOTC Working Party on Billfish Victoria, Mahé, Seychelles, July 4-8, 2011. 〈http://www.iotc.org/sites/default files/documents/proceedings/2011/wpb/IOTC-2011-WPB09-R\%5BE\%5D.pdf/.

Anon., 2012. Report of the Standing Committee on Research and Statistics (SCRS) of ICCAT. Madrid, Spain, October 1-5, 2012. 〈http://www.iccat.int/Documents/ Meetings/SCRS2012/2012_SCRS_REP_EN.pdf $\rangle$.

Anon., 2013. Report of the Standing Committee on Research and Statistics (SCRS) of ICCAT. Madrid, Spain, September 30-October 4, 2013. 〈http://www.iccat.int/Documents/Meetings/Docs/2013-SCRS-REP_ENG.pdf/.

Anon., in press. Report of the 2013 Atlantic Swordfish Stock Assessment Session. Olhao, Portugal, September 2013 (Doc. no. SCI-036/2013). http://www. iccat.int/Documents/Meetings/Docs/2013_SWO_ASSESS_REP_ENG.pdf

Block, B.A., Jonsen, I.D., Jorgensen, S.J., Winship, A.J., Shaffer, S.A., Bograd, S.J., Hazen, E.L., Foley, D.G., Breed, G.A., Harrison, A.-L., Ganong, J.E., Swithenbank, A., Castleton, M., Dewar, H., Mate, B.R., Shillinger, G.L., Schaefer, K.M., Benson, S.R., Weise, M.J., Henry, R.W., Costa, D.P., 2011. Tracking apex marine predator movements in a dynamic ocean. Nature 479, 86-90.

Block, B.A., Teo, S.L.H., Walli, A., Boustany, A., Stokesbury, M.J.W., Farwell C.J., Weng, K.C., Dewar, H., Williams, T.D., 2005. Electronic tagging and population structure of Atlantic bluefin tuna. Nature 434, 1121-1127, http://dx.doi.org/10.1038/nature03463.

Carey, F.G., 1990. Further acoustic telemetry observations of swordfish. In Proceedings of the second international billfish symposium part 2. In: Stroud, R.H. (Ed.), Kailua- Kona, Hawaii 1-5 August 1988,. , pp. 103-122, Natl. Coalition for Mar. Conserv., Savannah, GA.

Carey, F.G., Robinson, B.H., 1981. Daily patterns in the activities of swordfish, Xiphias gladius, observed by acoustic telemetry. Fish. Bull. 79, 277-292.

Davis, N., Pilling, G., Harley, S., Hampton, J., 2013. Stock Assessment of Swordfish (Xiphias gladius) in the Southwest Pacific Ocean. WCPFC-SC9-2013/SA-WP-05, $79 \mathrm{pp}$.

Dewar, H., Polovina, J., 2005. Deploying satellite tags on swordfish using the California harpoon fleet. Pelagic Fish. Res. Progr. Newsl. 10, 4-6.

Dewar, H., Prince, E.D., Musyl, M.K., Brill, R.W., Sepulveda, C., Luo, J., Foley, D., Orbesen, E.S., Domeier, M.L., Nasby-Lucas, N., Snodgrass, D., Laurs, R.M., Hoolihan, J.P., Block, B.A., Mcnaughton, L.M., 2011. Movements and behaviours of swordfish in the Atlantic and Pacific Oceans examined using pop-up satellite archival tags. Fish. Oceanogr. 2, 219-241 http://dx.doi.org/10.1111/j.1365-2419.2011.00581.x

Evans, K., Abascal, F., Kolody, D., Sippel, T., Holdsworth, J., Maru, P., 2014. The horizontal and vertical dynamics of swordfish in the South Pacific ocean. J. Exp. Mar. Biol. Ecol. 450, 55-67, http://dx.doi.org/10.1016/j.jembe.2013.10.025.

FAO, 2012. FAO Yearbook. Fishery and Aquaculture Statistics. 2012. FAO, Rome, pp. 76.

Fromentin, J.-M., Powers, J.E., 2005. Atlantic bluefin tuna: population dynamics, ecology, fisheries and management. Fish Fish. 6, 281-306, http://dx.doi.org/10.1111/j.1467-2979.2005.00197.x.

Galuardi, B., Royer, F., Golet, W., Logan, J.M., Neilson, J., Lutcavage, M., 2010. Complex migration routes of Atlantic bluefin tuna question current population structure paradigm. Can. J. Fish. Aquat. Sci. 67, 966-976, http://dx.doi.org/10.1139/F10-033.

García-Cortés, B., Mejuto, J., Quintans, M., 2003. Summary of swordfish (Xiphias gladius) recaptures carried out by the Spanish surface longline fleet in the Atlantic Ocean: 1984-2002. Collect. Vol. Sci. Pap. ICCAT 55 (4), 1476-1484. 
Hinton, M.G., Maunder, M.N., 2011. Status of swordfish in the Eastern Pacific Ocean in 2010 and outlook for the future. IATTC-SAC-02-09, $33 \mathrm{pp}$.

Holdsworth, J.C., Sippel, T.J., Paul, P.J., 2007. An investigation into swordfish stock structure using satellite tag and release methods. Biology Specialist Working Group Paper WCPFC-SC3-2007/BI WP-3. In: Proceedings of the 3rd Regular Session of the Scientific Committee of the Western and Central Pacific Fisheries Commission, 13-24 August 2007, Honolulu, HI.

Hoolihan, J.P., Luo, J., Abascal, F.J., Campana, S.E., De Metrio, G., Dewar, H., Domeier, M.L., Howey, L.A., Lutcavage, M.E., Musyl, M.K., Neilson, J.D., Orbesen, E.S., Prince, E.D., Rooker, J.R., 2011. Evaluating post-release behaviour modification in large pelagic fish deployed with pop-up satellite archival tags. ICES J. Mar. Sci. 68, $880-889$.

ICCAT, 2006-2014. ICCAT Manual. International Commission for the Conservation of Atlantic Tuna. In: ICCAT Publications [on-line]. 〈http://www.iccat.int/en/ICCATManual.htm〉, ISBN (Electronic Edition): 978-92-990055-0-7.

Josse, E., Bach, P., Dagorn, L., 1998. Simultaneous observations of tuna movements and their prey by sonic tracking and acoustic surveys. Hydrobiologia 371/372 (61-19).

Kasapidis, P., Valeiras, X., Antoniou, A., Kotoulas, G., García-Cortés, B., Mejuto, J., 2007. Generic and growth profiles of three specimens of swordfish (Xiphias gladius) tagged and recaptured in the North Atlantic. Collect. Vol. Sci. Pap. ICCAT 60 (6), 1964-1973.

Loefer, J.K., Sedberry, G.R., McGovern, J.C., 2007. Nocturnal depth distribution of western North Atlantic swordfish (Xiphias gladius, Linnaeus, 1758) in relation to lunar illumination. Gulf Caribb. Res. 19, 83-88.

Mejuto, J., García-Cortés, B., Ramos-Cartelle, A., 2005. Tagging-recapture activities of large pelagic sharks carried out by spain or in collaboration with the tagging programs of other countries. Collect. Vol. Sci. Pap. ICCAT 58 (3), 974-1000.

Musyl, M.K., Domeier, M.L., Nasby-Lucas, N., Brill, R.W., McNaughton, L.M., Swimmer, J.Y., Lutcavage, M.S., Wilson, S.G., Galuardi, B., Liddle, J.B., 2011. Performance of pop-up satellite archival tags. Mar. Ecol. Prog. Ser. 433, 1-28.

Musyl, M.K., Moyes, C.D., Brill, R.W., Fragoso, N.M., 2009. Factors influencing mortality estimates in post-release survival studies. Mar. Ecol. Prog. Ser. 396, 157-159, http://dx.doi.org/10.3354/meps08432.

Neilson, J.D., Smith, S., Royer, F., Paul, S.D., Porter, J.M., Lutcavage, M., 2009. Investigations of horizontal movements of Atlantic swordfish using pop-up satellite archival tags. In: Nielsen, J.L., Arrizabalaga, H., Fragoso, N., Hobday, A., Lutcavage, M., Sibert, J. (Eds.), Tagging and Tracking of Marine Animals with Electronic
Devices, Reviews: Methods and Technologies in Fish Biology and Fisheries, 9. Springer, New York, pp. 145-159 (452 pp).

Neilson, J., Arocha, F., Cass-Calay, S., Mejuto, J., Ortiz, M., Scott, G., Smith, C., Travassos, P., Tserpes, G., Andrushchenko, I., 2013. The recovery of atlantic swordfish the comparative roles of the Regional Fisheries Management Organization and species biology. Rev. Fish. Sci. 21, 59-97.

Neilson, J.D., Paul, S.D., Smith, C., 2007. Stock structure of swordfish (Xiphias gladius) in the Atlantic: a review of the non-genetic evidence. Collect. Vol. Sci. Pap. ICCAT 61 (1), 25-60

Nielsen, J.L., Arrizabalaga, A., Fragoso, N., Hobday, A., Lutcavage, M., Sibert, J., 2009 Tagging and Tracking of Marine Animals with Electronic Devices. Springer, Dordrecht Heidelberg London New York, pp. 452.

Palko, B.J., Beardsley, G.L., Richards, W.J., 1981. Synopsis of the Biology of the Swordfish, Xiphias gladius Linnaeus. FAO Fish. Synop. 127.

Pawlowicz, R., 2011. M-Map-mapping toolbox, Vers. 1.4f. 〈http://www.eos.ubc.ca/ $\sim$ rich/map.html $\rangle$.

R Core Team, 2013. R: A language and Environment for Statistical Computing. R Foundation for Statistical Computing, Vienna, Austria (ISBN 3-900051-07-0, URL http://www.R-project.org/).

Restrepo, V., 1990. An update of swordfish tagging data for use in growth analyses. Collect. Vol. Sci. Pap. ICCAT 32 (2), 360-370.

Royer, F., Lutcavage, M., 2009. Positioning pelagic fish from sunrise and sunset times: complex observation errors call for constrained, robust modeling. In: Nielsen, J.L., Arrizabalaga, H., Fragoso, N., Hobday, A., Lutcavage, M., Sibert, J. (Eds.), Tagging and Tracking of Marine Animals with Electronic Devices. Reviews: Methods and Technologies in Fish Biology and Fisheries, 9. Springer, New York, pp. 323-341 (452 pp).

Sedberry, G.R., Loefer, J.K., 2001. Satellite telemetry tracking of swordfish, Xiphias gladius, off the eastern United States. Mar. Biol. 139, 355-360.

Sepulveda, C.A., Knight, A., Nasby-Lucas, N., Domeier, M.L., 2010. Fine-scale movements of the swordfish Xiphias gladius in the Southern California Bight. Fish. Oceanogr. 19 (4), 279-289.

Takahashi, M., Okamura, H., Yokawa, K., Okazaki, M., 2003. Swimming behaviour and migration of a swordfish recorded by an archival tag. Mar. Freshwater Res. 54, 527-534.

Tal Sperling, A., Neilson, J.D., Carruthers, E.H., Stone, H.H., 2005. Compilation and analyses of Canadian conventional tagging data for swordfish (Xiphias gladius), 1961-2004. Collect. Vol. Sci. Pap. ICCAT 58 (4), 1483-1494. 